\title{
Institutional Performance of Mining Reclamation in Forest Areas of East Kalimantan
}

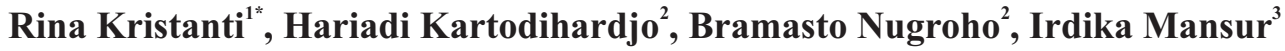 \\ 'Graduate Program of Forest Management Science, Faculty of Forestry, IPB University (Bogor Agricultural University), \\ Dramaga Campus, Bogor, Indonesia 16680 \\ ${ }^{2}$ Department of Forest Management, Faculty of Forestry, IPB University (Bogor Agricultural University), Dramaga Campus, \\ Bogor, Indonesia 16680 \\ ${ }^{3}$ Department of Silviculture, Faculty of Forestry, IPB University (Bogor Agricultural University), Dramaga Campus, Bogor, \\ Indonesia 16680
}

Received March 10, 2019/Accepted July 12, 2019

\begin{abstract}
The Indonesian Government accommodates the development of mining sector conducted in forest area based on Forestry Law Number 41/1999 by the scheme of Forest Leasehold License. Reclamation is required to remediate the degraded land caused by mining activity to restore forest structure and function. This study aimed to analyze the implementation of mining reclamation in East Kalimantan forest areas based on its institutional performance. This study is a descriptive qualitative study that implemented the institutional framework of Situation-StructureBehavior-Performance. From the study, we found that there are 143,804.89 ha of forest area borrowed by 90 units of Forest Leasehold License for coal and mineral mining in East Kalimantan with reclamation progress reached $41.35 \%$ over the disturbed areas. Based on institutional performance analysis, it is identified that the challenges in mining reclamation in East Kalimantan forest areas related to regulation, low sanction enforcement, lack of budget, human resource and economic incentives, and the absence of low-cost technology for mining reclamation monitoring and evaluation. Therefore, development of proper regulations is urgently required to improve stakeholder behavior while enhancement of human resource, technology, and law enforcement are also urgent to improve institutional performance of mining reclamation.
\end{abstract}

Keywords: reclamation, mining, externality, regulation, institutional

*Correspondence author, email: cumieinfahutan@gmail.com

\section{Introduction}

Mining activities, especially coal mining in Indonesia, is still considered essential to support national development. Coal production in 2007 reached 217 million tons and increased to 461 million tons in 2017, with annual average growth reached 5.29\%. In 2017, total coal export reached 298 million tons or equal to USD25.6 billion (MoEMR, 2018). Mining is perceived as a very complicated business, high risk, long-term activity, involves high technology and intensive capital, and relates with many other sectors, including forestry (Syaprudin et al., 2014). Positive influence of mining include generating state revenues from export, royalties, investment, taxes and non-tax state revenues, producing energy and mineral resources for development, improving community welfare through employment opportunities, corporate social responsibility programs, and infrastructure development in remote areas as well as enhancement of forest quality by implementing proper postmining rehabilitation (Suryanto \& Fernandes, 2010; DG Note:

Data from Directorate of Water and Soil Conservation, MoEF
Mineral and Coal, 2015). In order to boost national development, the government utilizes various natural resources, including mineral and coal resources (Nopyandri, 2014). Article 38 of Forestry Law Number 41/1999 mandates the use of forest areas to accommodate the interests on the non-forestry sector, including mining sector by the granting of Forest Leasehold License (FLL). This permit is released by the Minister of Environment and Forestry with consideration of area limitation, a period of time and forest sustainability. Based on data from the Ministry of Environtment and Forestry (MoEF), in 2018, MoEF has released 90 units of FLL for mineral and coal mining in East Kalimantan with a total area approximately $143,804.89$ ha as it is shown in Figure 1. This province plays an important role in mining development since it has the largest area of FLL as well as the biggest coal producer province in Indonesia (DG Mineral and Coal 2015). ${ }^{1}$

Although mining provides CSR programs and creates jobs for the local community, it also has negative impacts on the 


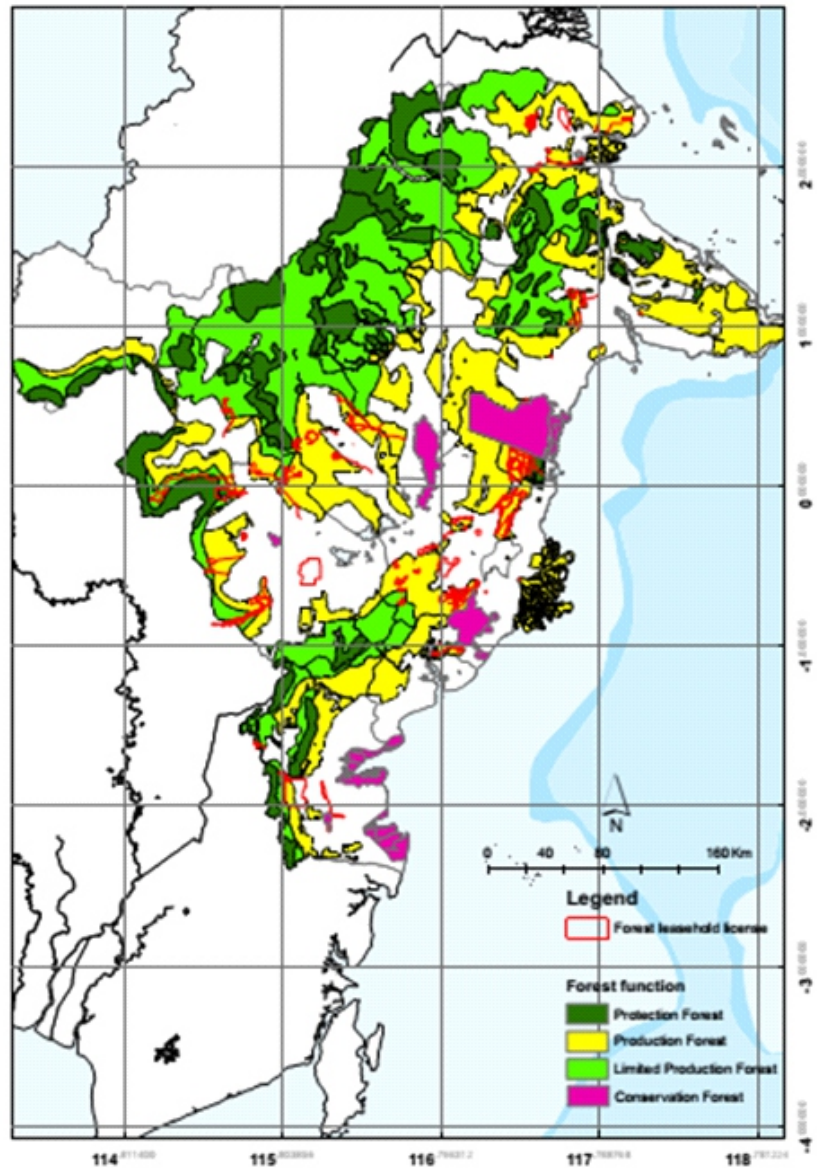

Figure 1 Development of Forest Lease License in East Kalimantan Province

ecological and socio-economic condition (Doley et al., 2012; Nasir et al., 2014; Saria, 2016). Increasing coal price generally increases coal production (MoEMR, 2018). This can have a negative impact on the environment if it does not apply good mining practice (Chang-sheng et al., 2009; DG Mineral and Coal, 2015; Azrin, 2016). Mining activities in the forest area are suspected of its contribution to forest destruction. Article 33 (2014) confirmed that forest destruction is caused by the lack of suitable mining practice implementation by mining companies. Mining is a massive and destructive activity that results in changes in the landscape. According to Ai-Bin (2009), externalities are the influence of business behavior on other aspects. Externalities are crucial in economic activities because they impact on resources and environmental conditions. Negative externalities of mining include declining reserves of mining materials and environmental impacts (Hirons et al., 2013; Pohan, 2014). Open pit mining that is commonly implemented in forest areas required the opening of forest cover. It may damage, disrupt, and even eliminate ecosystems, biodiversity, and forest services (Syaprudin et al., 2014). Mining in forest area also has negative effects on the forest ecosystem. It causes soil fertility decreases, soil compaction, erosion, sedimentation, landslide, microclimate changes, and disruption of the health of communities around mining area (Fahruddin \& Abdullah, 2013; Nasir et al., 2014; Anawar, 2015; Muis et al., 2016).

Mining management requires the study of mining business feasibility and mine closure planning, which includes overcoming socio-economic problems and environmental protection (Kumar, 2014). Internalization is defined as environmental and social protection that is directly related to a mining operation (Peck \& Sinding, 2009). In a judicial perspective, mining reclamation is obligated to mining companies. It is part of environmental management that require proper mining techniques. As part of the internalization of mining externalities, reclamation aims to restore disturbed forest area caused by mining activity in order to enhance the quality of forest area based on its functions (Gradinaru, 2014). The main problem is that it is difficult, if not impossible, to restore forest function and structure completely since reclamation is not always in line with the mining plan (Dariah et al., 2009).

Opportunities and challenges in mining reclamation in forest areas arise from various situations, information, and access to benefit and response to situations due to the implementation of rules by involved stakeholders. Furthermore, Ostrom (1990) and Fischer et al. (2007) described that one of the main factors influencing natural resource management institutions is a formal and informal regulatory framework. In this study, an institutional approach was applied to identify the character of mining reclamation, regulations that govern mining reclamation and behavior of related stakeholders in carrying out FLL reclamation. These three institutional elements define FLL institutional performance. Based on those conditions, one main emerging question is the state of mining reclamation in East Kalimantan forest area based on its institutional approach. This study seeks to illustrate the institutional performance of FLL mining reclamation from the aspect of mining negative externality, FLL reclamation business process and its implementation, and FLL reclamation utilization.

\section{Methods}

This research is a descriptive study that is mainly based on a qualitative approach (Creswell, 2016). This study implemented an institutional framework of Structure, Situation, Behavior, and Performance (SSBP) developed by Nugroho (2016). It describes the elements of an institution that consist of situation or characteristics of resources, institutional structure, behavior, and performance. In this framework, the situation represents the socio-physical and biophysical conditions of FLL. Structure refers to a set of rules governing FLL reclamation. Behavior represents the attitude of stakeholders in conducting FLL reclamation. These three institutional framework elements determine the institutional performance of mining reclamation in East Kalimantan forest areas as it is described in Figure 2.

This research focused on reclamation activity conducted by FLL holders. East Kalimantan Province is chosen as the focus area since it is the biggest coal producer at the national level (DG Mineral and Coal, 2015). In addition, this province has an extensive mining area covering 5.13 million hectares or $40.3 \%$ of the total area of the province of 12.91 million 


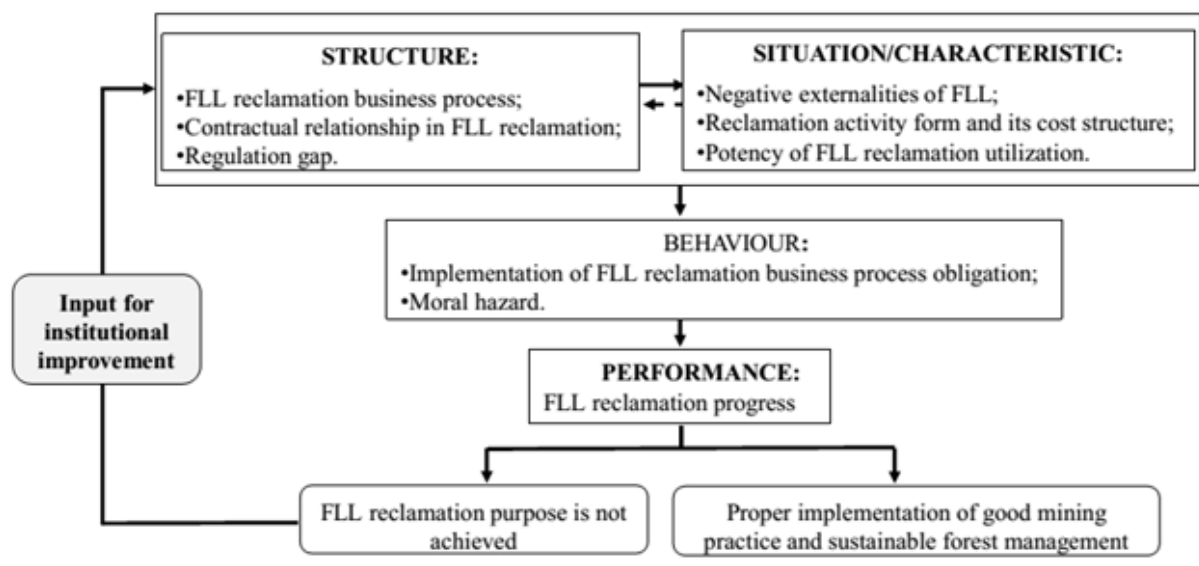

Source: Development of SSBP Institutional Framework (Nugroho, 2016)

Figure 2 Structure-situation-behavior-performance institutional framework.

hectares (Statistics Indonesia, 2018). Data collection was carried out for six months, from January to June 2018. Types of data used in this study are primary and secondary data. Primary data were obtained from interviews and field observations focusing on mining impacts to the community, reclamation implementation, and stakeholders' behavior. Primary data were extracted from in-depth interviews using open questions (Polit \& Beck, 2012) from 70 resource persons determined by snowball sampling. Resource persons are involved in FLL reclamation from government institutions, mining companies, academicians, nongovernment organizations, and local community around mining areas.

The related institutions consist of Directorate General of Watershed and Protected Forest Management (under MoEF) Directorate General of Forest Planning and Environmental Management (under MoEF), Forestry and Environmental Research and Development Agency (under MoEF), Directorate General of Mineral and Coal (Ministry of Energy and Mineral Resources/MoEMR), Corruption Eradication Commission, East Kalimantan Forestry Agency, East Kalimantan Provincial Energy and Mineral Resources Agency, Mahakam Berau Watershed Management Office, Production Forest Management Unit (Berau Barat, Damai, Meratus), East Kalimantan Environmental Agency, East Kalimantan Supervisory Commission on Reclamation and Post-Mining, FLL holders in Berau, Kutai Barat, Kutai Timur, and Kutai Kartanegara Districts as reclamation observation units, former Energy and Mineral Resource Agency and Forestry Agency of Berau, Kutai Barat, Kutai Kartanegara, and Kutai Timur Districts, non-government organizations, forums on mining reclamation, and research institutions. While secondary data were obtained by literature studies on reclamation documents from related stakeholders.

This study applied a qualitative descriptive method with qualitative content analysis and gap analysis techniques.
Content analysis was implemented to find, identify, process, and analyze the overall description both expressed and embedded from the documents (Sartika, 2014). A gap analysis was applied as the continuation of content analysis to analyze the gap between the regulation and the implementation (Rosli \& Rossi, 2014).

\section{Results and Discussion}

Negative externalities of mining in forest area Mining is a long-term and complex activity that includes investment, revenue gain, and rehabilitation phases. Investment phase covers exploration activities and feasibility study. Mining exploration includes preliminary exploration and comprehensive exploration that takes eight and four years each. Exploration is continued by a feasibility study in $2-5$ years. The initial stages of mining licensing are started with accomplishing the obligation of environmental documents, including environmental impact analysis, environmental management, monitoring, and their validations. The revenue phase starts from increasing exploration stage to production stage based on the feasibility study. If the mining area is in forest areas, the mining license holder must have FLL from the MoEF. Mining licenses for coal production released by East Kalimantan local government (formerly issued by the head of the district) are generally given for a period of 5-24 years. Mining licenses issued by the MoEMR as the central government are generally given for a period of 30 years. The mining license holder must allocate reclamation budget to support reclamation activity as an obligation to the environment and local community around the mining area. Mining activities must be in line with the efforts to minimize the negative impact on the surrounding environment. Thus, reclamation must be carried out in line with the stages of coal production $^{2}$.

Mining activities in forest areas can be carried out through FLL scheme based on MoEF Decree Number 27/2018 concerning the Guideline of FLL. Forest areas that can be

\footnotetext{
2 The result from discussion with several FLL holders
} 
Table 1 Reclamation progress of forest lease license per district in East Kalimantan

\begin{tabular}{|c|c|c|c|c|c|}
\hline District & $\begin{array}{l}\text { FLL } \\
\text { (unit) }\end{array}$ & $\begin{array}{l}\text { FLL area } \\
\text { (ha) }\end{array}$ & $\begin{array}{l}\text { Disturbed area } \\
\text { (ha) }\end{array}$ & $\begin{array}{l}\text { Reclamation } \\
\text { area (ha) }\end{array}$ & $\begin{array}{c}\text { Evaluated and/or returned } \\
\text { area (ha) }\end{array}$ \\
\hline Berau & 11 & 9.425 .52 & 2.023 .18 & $557.20(27.54)$ & - \\
\hline Kutai Kartanegara & 38 & 83.456 .59 & 26.126 .79 & $10.755 .83(41.17 \%)$ & $417.39(1.60 \%)$ \\
\hline Kutai Timur & 12 & 7.525 .83 & 2.332 .09 & $990.89(42.49 \%)$ & $215.35(9.23 \%)$ \\
\hline Kutai Barat & 23 & 28.722 .97 & 5.552 .70 & $2.855 .57(51.43 \%)$ & - \\
\hline Paser & 4 & 13.898 .12 & 1.645 .25 & $422.87(25.70 \%)$ & - \\
\hline Penajam Paser Utara & 2 & 775.86 & - & - & - \\
\hline Total & 90 & 143.804 .89 & 37.679 .98 & $15.582 .36(41.35 \%)$ & $632.74(1.68 \%)$ \\
\hline
\end{tabular}

Source: Directorate of Soil and Water Conservation, MoEF (2018)

Note: $\mathrm{FLL}=$ Forest lease-hold license

assigned for mining by FLL scheme include production forest and protected forest. Mining activities in production forests can implement two mining techniques: open mining and underground mining. Open mining technique is the most commonly used technique in mineral and coal mining in Indonesia. Mining activities in protected forests may only apply underground mining technique to minimize landscape change. In Article 42 it is mentioned that one of the obligations of FLL holder is to conduct reclamation as part of a contractual scheme between MoEF and FLL holder.

As is the case with the utilization of natural resources in general, coal mining also creates negative externalities to environment component. The impact on biotic and abiotic components is the increase of surface run-off, sedimentation, air and noise pollution, water, soil and air quality decrement, landscape, microclimate changes, and disturbance of land and river transportation. While the negative impact of biotic component is the disturbance on the habitat and the existence of flora and fauna living in the forest. Meanwhile, on social components, externalities are in the form of potential social conflicts, loss of sources of income from forest land and its products as well as health problems to the people around the mining area.

In general, FLL areas are used for mining pit, soil stock, erosion control and supporting facilities, including processing and refining plants, waste ponds, housing, roads, warehouse, office, workshop, port, and landfill. Negative externalities from a mining operation in forest area are generated from every stage of mining. It is started from land clearing for infrastructure development and mining pit. Land clearing causes impact to the social economic condition of the local community. It eliminates the benefit of forest land in supporting agricultural activity as a dominant source of income for the local community around the mining site. Land clearing is followed by topsoil stripping, blasting, overburden removal, coal extraction, processing, and transporting. These activities increase erosion rates by 94-200 times. River flow fluctuations also trigger floods or droughts and also decrease water quality and biotic conditions.

Furthermore, coal mining activities generally produce acid mine drainage (AMD) that is created when groundwater is exposed to coal and air in particular in coal washing activities. The local community surrounding FLL areas is the biggest recipient of negative mining impact because of AMD production. Soil and water pollution affect the river that is important for people as a water supply for farming, gardening, drinking, washing, bathing, and cooking. The pollution changes the water into brown or moreover black color. Brown water indicates the water contains sediment from the surface run-off while the black water indicates the presence of AMD

Mining impact to the forest is the decrement its vegetation and wildlife diversity as well as diminishing forest function. These impacts are considered as a significant impact on the environmental impact analysis from all FLL holders in this study. This significant impact is evaluated by the evidence of the total number of impacted people, size of the impacted area, intensity and period of the impact, the number of impacted environment component, cumulative impact characteristic and reversibility from impact. Landscape change occurs due to the formation of mining pits with a depth of more than 40 meters. The very significant impact of mining activity is on soil conditions. The use of heavy equipment in mining operation such as bulldozers, loaders, excavators, long vehicles, and dump trucks results in soil compaction that effects revegetation progress. Formation of overburden stock with $20-40 \mathrm{~m}$ height also results in erosion and sedimentation. Eroded soils are transported to the river and disturb communities' health as well as the mobility in a mining operation that produces dust and air pollution. Air and water pollution results in respiratory infections, skin diseases, diarrhea, and dysentery.

The land is natural resources that are very important and valuable for the local community. They claim that they depend on the existence of forest lands for agriculture like to cultivate paddy, cassava, vegetables, rubber, coconut, and plantation that produce fruit or resin. Although mining creates a positive impact by creating job opportunities, it also brings negative impact to the local economy. Negative externalities directly influence their access to the forest and its products. Community's economy is disrupted due to the loss of employment in the agricultural and forestry field as their dominant source of income. Mining is an exclusive activity with high technical risks. It causes the access to enter the mining area is very limited. The impact of FLL relates to disrupted accessibility that is the closed transportation access for the local community. As an impact, the community must establish new road access or reroute the existing access that causes higher transportation cost. Another alternative that can be used by the community is river transportation. However, transportation through river reduce travel time so 
that it is more efficient in terms of time but high in transportation cost due to the fuel price. It greatly affects the daily economic mobility including education for the young generation living there. In the other hand, mining is perceived to open access for the community around the mining site in utilizing forest areas and its products. It caused a problem to FLL holders since the existence of the local community that occupies FLL areas disturb the reclamation plantation. It causes the higher cost to FLL holders to provide compensation, to protect FLL areas intensively or to get rid of the local community from FLL areas ${ }^{3}$.

Forest leasehold license reclamation policy and implementation East Kalimantan Province plays an important role in mining and mining reclamation at the national level. The MoEF has issued 90 units of FLL in East Kalimantan covering an area of $143,804.89$ ha with total disturbed area reached $37,679.98$ ha. FLL reclamation reached $15,582.36$ ha $(41.35 \%)$ of total disturbed area. The tariff FLL levy based on Government Regulation Number 33/2014 concerning FLL Levy and opportunity to increase quota size for FLL based on MoEF Decree Number 27/2018 concerning Guidelines of FLL become incentives for FLL reclamation. The area of 632.74 ha of total disturbed area $(1.68 \%)$ was assessed to deduct FLL levy. Those assessed areas consist of five FLL holders area including one holder in Kutai Barat District and four holders in Kutai Kartanegara District. Furthermore, one of those five holders has returned the reclamation area to the MoeF in order to release its reclamation area to acquire increment of FLL quota size to expand its mining operation.

When it is compared to the development of FLL reclamation at the national level, total FLL in Indonesia is 606 units covering 450,490.92 ha. The disturbed area reached $78,912.85$ ha with reclamation progress reached $29,246.67$ ha $(37.06 \%)$ of the disturbed area. Reclamation area that had been assessed reached $1,671.11$ ha $(2.12 \%)$. Thus, by comparing reclamation progress between East Kalimantan and national level, we can see that although total FLL in East Kalimantan only $14.85 \%$ from FLL for mining in Indonesia, it covered one third FLL areas and reclamation progress of $53.28 \%$ at national level ${ }^{4}$.

Refer to the US Surface Mining Control and Reclamation Act, Hall (1987) described the efforts to support sustainable mining implementation. These include providing national program for environment rehabilitation from mining impacts, reclamation implementation based on mining sequence, ensuring the balance between mining activities with environmental protection and conservation of land productivity, reaching conditions that are close to or more improved than the conditions before mining, ensuring public participation in policy arrangement and its implementation, the existence of standards and planning for reclamation, and supporting the government in enforcing the rules to achieve the objectives of reclamation in accordance with regulatory framework. To internalize the negative impacts of FLL, the government regulates the management of mining reclamation in forest area through various regulations. From

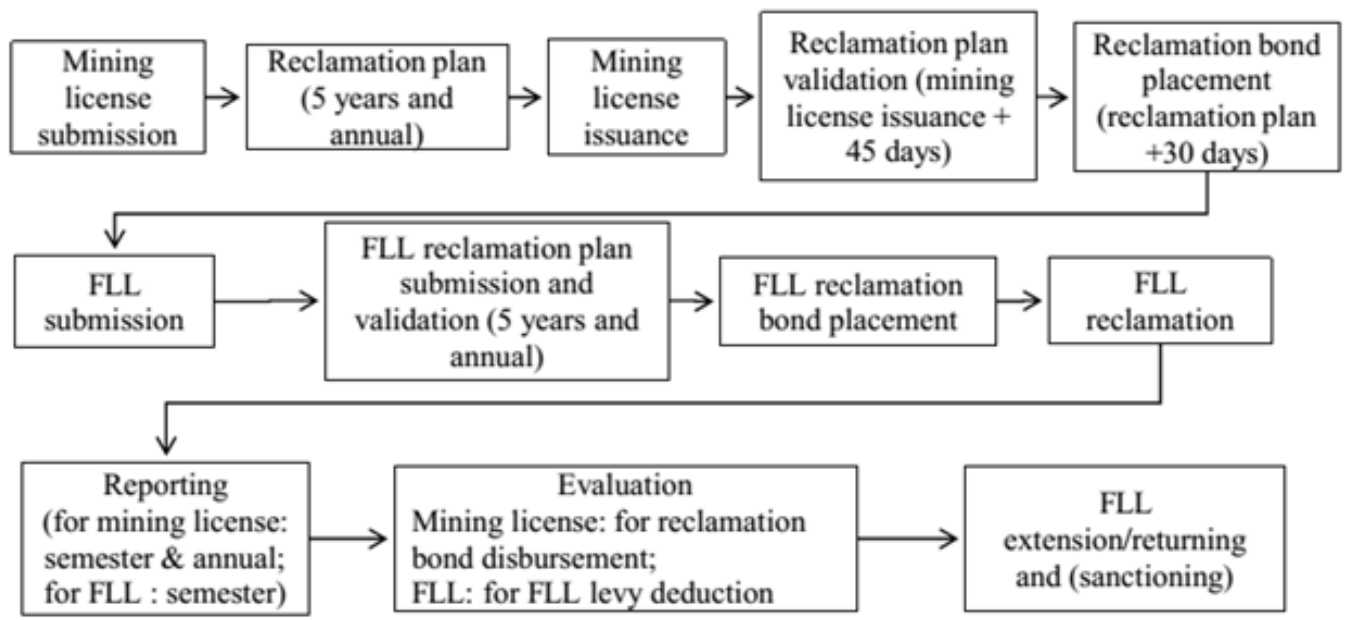

Figure 3 Business process of mining reclamation in forest area in East Kalimantan Province.

\footnotetext{
Result from discussion with several reclamation managers in FLL holders in Kutai Barat, Berau, Kutai Kartanegara, and Kutai Timur District, reclamation experts, local communities and analysis of environmental impact analysis documents from several FLL holders

Result from data analysis from Directorate of Soil and Water Conservation, MoEF (2018)

5 Forestry Act No. 41/1999, Mineral and Coal Act No. 4/2009, Local Government Act No. 23/2014, Government Regulation No. 76/2008 concerning Forest Rehabilitation and Reclamation, Government Regulation No. 78/2010 concerning Reclamation and Post-Mining, Government Regulation No. 33/2014 concerning FLL Levy, MoEF Decree No. 60/2009 concerning Guideline for the Assessment of Forest Reclamation Progress, MoEF Decree No. 39/2010 concerning General Pattern, Criteria and Standard for Forest Rehabilitation and Reclamation, MoEF Decree No. 4/2011 concerning Guideline for Forest Reclamation, MoEF Decree No. 84/2014 concerning Guideline for Disturbed Area, Reclamation and Revegetation Area Calculation for FLL Levy Counting, MoEF Decree No. 27/2018 concerning Guidelines of FLL, MoEMR Decree No. 26/2018 concerning Good Mining Practice and Mining Monitoring, MoEMR Verdict No. 1827/2018 concerning Guideline for Good Mining Practice, East Kalimantan Provincial Regulation No. 8/2013 concerning Reclamation and Post Mining Implementation and No. 1/2014 concerning Environment Protection and Management and East Kalimantan Governor Regulation No. 38/2015 concerning Guideline of Land Reclamation and Revegetation and Mining Closure in East Kalimantan Province.
} 
the study of related regulations ${ }^{5}$, the flow of the FLL reclamation business process is compiled as it is described in Figure 3.

The government has arranged FLL for mining activities, including mining reclamation through various policies which are top-down policy (Zubayr, 2014). The purpose of these regulations is to manage the operation of reclamation carried out by FLL holders in order to achieve good mining practice and to restore forest function after mining is accomplished. Mining regulations drive mining license holders to manage and monitor mining environments including reclamation activity. Mining reclamation requires a feasibility study supported by mine closure planning covering environmental protection and prevention of socioeconomic problems. Currently, natural resources management still relies on command and control policies. These are considered to be less efficient, complicated, resources consuming especially for its monitoring and evaluation, having limitations in implementation and rigid towards innovation (Gossum et al., 2012). The effort in environmental management in the form of regulation as a command and control policy in Indonesia is still ineffective to control environmental risk caused by economic activities (Gunarto et al., 2009). In the implementation of FLL reclamation in Indonesia, there are various technical and non-technical constraints which include (1) lack of soil supply and acid mine drainage problems, (2) limited capacity of reclamation experts, (3) conflict with between mining company and local community due to lack of community empowerment and limitations of mining conflict management model in forest areas ${ }^{6}$. These obstacles also occur in the implementation of FLL reclamation in East Kalimantan. This is indicated by the following facts based on the FLL reclamation business process:

a. Reclamation Plan and Reclamation Bond

The initial process that critically influences mining reclamation performance is a reclamation plan. This document contains information about forest area condition before, during, and after mining activity is conducted, plan for land clearing, plan for reclamation, and its budget based on a feasibility study and environmental impact analysis. Mining license holder for exploration activity must submit five years plan and annual reclamation plan together with mining production permit application to mining license issuance authority, in this case, is MoEMR or governor. For following reclamation plan, the mining license holder must submit a reclamation plan no later than 45 days before the previous reclamation plan expiration date. The document is submitted to MoEMR or governor based on their authority and to be assessed within 30 days after the mining permit is issued.

Before the enactment of Act Number 23/2014, reclamation plan obligations were not optimally fulfilled by the holders of mining license issued by the local government.
Before the enactment, many of FLL holders as the holder of mining license issued by the local government did not submit a mining reclamation plan. Even if they did, mostly reclamation plan was only a formality as a requirement for mining license issued by the local government. Based on reclamation plan and reclamation bond data from East Kalimantan Energy and Mineral Resource Agency, before the enactment of Act Number 23/2014, from 55 FLL holders as the holder of mining license issued by local government, there are only 35 holders $(63.63 \%)$ that have submitted reclamation plan whereas the other 20 did not fulfill the obligation. From those 35 holders, 22 holders submit their reclamation plan overdue the schedule based on the regulations. It is a form of regulation violence since they have to submit a reclamation plan together with mining license submission before the authority issues mining license. By the enactment of Act Number 23/2014, from those 22 holders, 11 holders have improved their responsibility to submit their upcoming five years reclamation plan on schedule and in line with their mining plan?.

Based on data from Directorate General of Mineral and Coal (MoEMR), compared with the holders of mining license released by local government, in 2018, from 35 FLL holders that hold mining license issued by central government, there are 31 holders $(88.57 \%)$ have submitted reclamation plan whereas the 4 holders have not submitted. These four holders are not recorded submitting reclamation plan and placed reclamation bond to MoEMR. Based on data from MoEF, these four holders consist of 2 holders that have conducted mining activity with no reclamation progress yet, one holder has not to conduct mining operation, and the other one holder is active mining with reclamation progress reached 54\% from disturbed areas. From descriptions above, it is shown that not all mining license issued by central government has a strong commitment in fulfilling reclamation plan obligation despite the fact that they are more committed compared with mining license issued by local government holders. However, still, it is a form of regulation violence in fulfilling the reclamation plan obligation.

According to Peck and Sinding (2009), the fundamentals of sustainable mining activities consist of good corporate governance to maintain the reputation and integrity of mining business, provide a clear, effective and specific implementation framework related to the distribution of benefits and the costs of internalizing the impact of mining and providing markets and financial guarantee. Reclamation bond is an amount of money placed to the government as a guarantee to ensure the mining company to conduct reclamation after mining activity is accomplished. Before the enactment of Act No. 23/2014, the amount and placement of reclamation bond, especially by the holders of mining license issued by local government were not optimal. After

\footnotetext{
Presented by Director of Soil and Water Conservation (MoEF) at Forest Reclamation in Post Mining Land Forum - Jakarta International Forestry Promotion, 4 February 2016 in Jakarta

Information from the apparatus of East Kalimantan Energy and Mineral Resource Agency, East Kalimantan Environment Agency and East Kalimantan Supervisory Commission on Reclamation and Post-Mining and data analysis results from reclamation bond, reclamation plan and reclamation progress from East Kalimantan Energy and Mineral Resource Agency
} 
the enactment of Act Number 23/2014, there are 11 mining license holders released by the local government had placed reclamation bond whereas before the enactment they did not place it. The enactment of Act Number 23/2014 does not significantly improve the commitment of mining license issued by central government holder in placing their reclamation bond. From 35 FLL holders, there are only eight holders that place their reclamation bond on schedule and are listed by MoEMR while the other seven holders have not placed reclamation bond, and another 20 holders have placed their reclamation bond without any clear information about the placement date ${ }^{7}$.

As Schmid (1987) described, to fulfill obligations that are bounded by the contract, the agent in this term is FLL holder must incur operational costs, which result in profit decrement. Ai-Bin (2009) stated that environmental cost is mainly spent on compensating and eliminating the damage to the environment caused by resource exploitation. In terms of reclamation bond amount, in Kutai Kartanegara District and Penajam Paser Utara District, the holder of mining license issued by the local government mostly placed reclamation bond of IDR20-30 million ha ${ }^{-1}$. It increased to IDR40-60 million $\mathrm{ha}^{-1}$ after the implementation of the Act that effectively started in late 2016. In 2016, the Governor of East Kalimantan set a minimum amount of IDR70 million ha ${ }^{-1}$, which had a positive impact on the increment of reclamation bond amount. This is shown by the amount of reclamation bond placement after 2016 that reached IDR51-136 million $\mathrm{ha}^{-1}$. The holder of mining license issued by the local government that did not place reclamation bond before the Act was also more committed to placing reclamation bond after the enactment of the Act. One of the triggers is the policy to suspend mining license issued by local government extension if the reclamation bond had not been placed. Currently, from 90 FLL holders, 66 holders (35 mining license issued by local government and 31 mining license issued by central government) have been recorded committed to reclamation plan and reclamation bond obligations ${ }^{11}$.

The amount of reclamation costs is very specific for each FLL holder. It is influenced by former forest condition, type, and location of deposits, the magnitude of impact, mining and reclamation techniques, and also company policies that determine the allocation for reclamation resources. Reclamation cost of the holder of mining license issued by local government ranged from IDR74-79 million ha ${ }^{-1}$, while in the holder of mining license issued by central government the cost ranged IDR175-370 million $\mathrm{ha}^{-1}$. Reclamation component that requires the largest allocation of costs is land and soil management that is very influenced by soil characteristics impacted by the mining. Soil management must be carried out through appropriate treatment to meet successful revegetation that requires high technology cost ${ }^{8}$.

Fulfillment of reclamation bond placement does not eliminate reclamation obligation. The disobedience of mining reclamation triggered by the amount of reclamation bond placement that is less than the actual reclamation cost. One FLL holder in Berau District required actual reclamation cost in the year of 2017 of IDR370 million, but the placement of reclamation bond was only IDR290 million. Furthermore, one of FLL holders in Kutai Kartanegara District placed reclamation bond in the year of 2018 for IDR56 million ha ${ }^{-1}$ while the actual cost reached reach IDR79 million ha ${ }^{-1}$. As Lin-lin and Zen-qhi (2009) described, reclamation bond amount, which is smaller than the actual cost potentially trigger disobedience of mining reclamation behavior. Mining businesses tend to ignore reclamation because they consider the reclamation bond is sufficient to cover reclamation cost through third parties, in particular, the company that not concerned with the brand image.

To support mining operation, the mining license holder is obligated to arrange the Annual Work and Budget Plan and to be validated by mining license issuer authority. In that document, information about technical mining operation, including reclamation activity, is described. The information related to reclamation consists of disturbed area, reclamation activity, and budget from the current and upcoming year. It is used as a guideline for a mining license holder to conduct their reclamation activity. This document has to be validated by mining license issuer authority, which is Minister of Energy and Mineral Resource or the governor.

In 2016, from 55 FLL holders, there are only 15 holders that submitted Annual Work and Budget Plan and were validated by East Kalimantan Energy and MoEMR. It means that the other 40 FLL holders did not submit their Annual Work and Budget Plan. Most of them located in Kutai Barat Districts followed by Kutai Kartanegara Districts. In 2017, the number of FLL holders that submitted Annual Work and Budget Plan increased from 15 holders in 2016 to 35 FLL holders in 2017. It showed that in 2017, 20 FLL holders did not submit their Annual Work and Budget Plan. From those 20 holders, most of them located in Kutai Kartanegara District followed by Kutai Barat District. The improvement from 2016 to 2017 was supported by the implementation of Act Number 23/2014 that is effectively implemented two years after its enactment or late of 2016. Compared with the previous two years data, in 2018, the FLL holders that submitted their Annual Work and Budget Plan decreased to 27 holders from 35 holders in 2017 . The other 28 holders did not submit their Annual Work and Budget Plan that mostly located in Kutai Barat District followed by Kutai Kartanegara District. The decrement was caused by the stagnancy of their mining production that is caused by a conflict with the local community especially those in Kutai Barat District or postponed caused by coal price, technical and human resource consideration.

From data series of 2016, 2017, and 2018, there are only 10 FLL holders that are consistent to comply Annual Work and Budget Plan obligation. From those 10 FLL holders, six holders have conducted mining and reclamation in forest areas with reclamation progress ranged from $22.93 \%$ to $70.41 \%$ with an average of $39.36 \%$. The ignorance of submitting Annual Work and Budget Plan indicates the FLL holder's commitment to conduct good mining practice, including reclamation activity. This ignorance violence the

\footnotetext{
Results from the study of environmental impact analysis, feasibility study and activity and Annual Work and Budget Plan from several FLL holders also from mining reclamation bond placement data from MoEMR and East Kalimantan Energy and Mineral Resource Agency as well as from the discussions with reclamation managers in several FLL holders
} 
regulations that govern the mining holder's obligation to arrange an Annual Work and Budget Plan. It is also showed that Kutai Barat District and Kutai Kartanegara District are the most two districts with the lowest commitment of FLL holders to meet the Annual Work and Budget Plan submission obligation. The condition of Kutai Barat District related to the fulfillment of Annual Work and Budget Plan is in line with the reclamation progress in the district that is $0 \%$ from the total disturbed area of 924.16 ha. However, this progress in Kutai Kartanegara District is not in line with the reclamation progress of FLL holders as the holders of mining license issued by the local government as it is the third most complied district in reclamation with reclamation progress reached $30.41 \%$.

Based on Article 48 and 49 of Government Regulation Number 76/2008, FLL holders must submit reclamation plan to be assessed by the Director General of Watersheds and Protection Forests Management, MoEF and authorized by the MoEMR or governor. FLL holders must also place FLL reclamation bond to MoEF. Currently, MoEF has not governed following regulation from Government Regulation Number 76/2008. It became disincentive since the obligation of FLL reclamation plan and reclamation bond are important as a guideline for FLL holder to conduct reclamation and for MoEF to conduct mining reclamation in forest areas.

b. Reclamation Implementation and Evaluation

Implementation of reclamation based on the proper plan and mining stage can improve reclamation quality and minimize reclamation cost. As Mansur (2017) stated, without proper planning, mining can create environmental impacts and cause high reclamation costs to restore the forest. Regarding reclamation cost, the portion of reclamation costs for the production and profit costs of FLL holders is quite diverse. For example, one FLL holder that hold mining license issued by local government in Berau District required reclamation cost $3.4 \%$ of total production cost where one holder in Kutai Kartanegara District required reclamation cost only $0.33 \%$ of production costs or equal with $0.52 \%$ of the net profit where other required $11.77 \%$ of production cost or equal with $1.94 \%$ from total net profit. As for mining license issued by central government holders, one holder in Berau District required reclamation costs $0.72 \%$ of production costs or $12.56 \%$ from net profit where one in West Kutai District required reclamation costs of $0.26 \%$ from production cost or $2.43 \%$ from net profit. From those, where reclamation required a ve ry small portion of production costs, it should be considered as an incentive for the rationality of FLL holders to conduct reclamation. Ideally, reclamation cost is allocated $10 \%$ of the production costs and is bigger portioned of net profit to increase the commitment of FLL holders to carry out reclamation'.

Reclamation is strongly influenced by coal price. High prices of coal resulted in re-disturbing of recent reclamation result. Decreasing prices resulted in reclamation postponement since it influences the financial structure of the company that limits the capacity to conduct reclamation ${ }^{10}$. FLL holders are required to report annual mining reclamation progress to MoEMR or governor no later than 31 January in the upcoming year and be evaluated in a maximum of 30 days from report submission. The assessment results are used to determine reclamation bond disbursement. FLL holders are also required to report quarterly and annual FLL reclamation progress to Director General of Watershed Management and Protection Forest. However, this obligation has not been properly implemented by FLL holders, although it has been facilitated by ereporting. The absence of sanctions enforcement to FLL holder that disregard reclamation obligation is a disincentive in supporting reclamation progress. This disincentive is tackled by the policy of the assessment of activity and budget plan document where mining permit holders are prohibited from carrying out mining operation in the following year if they do not obtain activity and budget plan approval from the Director General of Mineral and Coal MoEMR or the Head of Provincial Energy and Mineral Resource Agency. The success of reclamation must be supported by effective, in this case is fast, cheap, and easy to implement, monitoring and evaluation. This can be done by applying spatial technology to have a fast, accurate, and consistent result of reclamation evaluation (Muis et al., 2016). Although spatial monitoring can be implemented, it has not supported yet by the readiness of budget, technology, and human resource from the government institutions. Field monitoring is constrained by budget availability. For example, before 2014, Mahakam Berau Watershed Management Agency was able to monitor 25 FLL units annually. After 2014, FLL reclamation monitoring activities were merged with the obligation of FLL watershed rehabilitation. It caused budget limitation to conduct reclamation monitoring ${ }^{11}$.

Ministry of Energy and Mineral Resource or governor as the authority in mining license issuance supervises mining reclamation by mining inspector. Mining inspector is given authority to visit mining site and conduct inspections, investigations and assessment of reclamation and terminate mining activities if it is indicated caused environmental damage. In reclamation, constraints due to the minimum number of mining inspector in East Kalimantan of which only 58 mining inspector who had to monitor over 400 active mining licenses issued by the local government. In addition, another constraint is on budget limitation. The annual budget that is allocated, which is only IDR 100 million is considered to be very insufficient to be used by 58 mining inspectors for conducting good mining practice monitoring, including reclamation. In addition to limited mining inspector and budget, no regulation manages FLL Reclamation Technical Officers. The role of this officer is necessary for supporting mining reclamation in particular in the forest area. Furthermore, the governor as an authority in issuing mining license in accordance with Act Number 23/2014 must report the implementation of reclamation in the province at least

\footnotetext{
9 The results of the study of feasibility study and Activity and Budget Plan documents from several FLL holders and discussion with the member of the provincial team for FLL reclamation assessment.

${ }^{10}$ Information from several FLL holders

${ }^{11}$ Information from the apparatus in the MoEMR, MoEF and its agencies in East Kalimantan
} 
every six months to the MoEMR. The MoEMR must supervise the implementation of reclamation under governor supervision $^{12}$.

In relation to the success criteria of reclamation, there are FLL holders and evaluators who still do not properly understand the reclamation criteria based on the MoEMR Decree Number 1827/2018 and MoEF Decree P.60/2009. This affected on high reclamation costs, especially soil management aspects that reach 10-12 times of revegetation costs. In addition, improper reclamation planning based on the feasibility study and environmental impact analysis has an impact on the ability of FLL holders to meet the criteria. The criteria that are considered limiting for reclamation is revegetation aspect. Technical and non-technical constraints include the obligation to plant local plants which is less adaptive to the mining soil, conflicts with communities due to their interest to plant oil palm or other plants that are not in accordance with the reclamation criteria and land occupancy by local community of which happened in several FLL in Kutai Kartanegara and East Kutai District. The regulation that has been implemented is not adequate to control the behavior of the stakeholders in FLL reclamation ${ }^{13}$.

The East Kalimantan Government requires mining license issued by local government holder to carry out reclamation of at least $70 \%$ of the total quantity number of the pit and conduct revegetation of at least $40 \%$ of the reclamation area that when mining license issued by local government holder tend to increase its coal production. This policy is one of the efforts to bind the commitment of mining license issued by local government holder in conducting reclamation. This policy also has its weakness regarding the implementation. The mining company can use its strength in mining techniques to avoid the obligation to disclose its mining pit. Furthermore, the limited area of FLL constrains the mobility of active overburden management that is slowing the reclamation progress and decrease soil quality for revegetation.

The mining license holder must carry out reclamation no later than 30 calendar days after mining activity is accomplished. Reclamation is not carried out on time that is generally caused by technical constraints such as lack of overburden soil, non-technical aspect like decrement of coal prices which disrupt the financial capacity of FLL holder especially mining license issued by local government holder or even more conduct re-disturbing when coal price is increasing. In addition, the reclamation area that has been assessed and returned to MoEF only reached $1.68 \%$ from the disturbed area. It is triggered by regulation that stipulates that assessed or returned reclamation area can be reused after one rotation of the primary crop. This is a disincentive for reclamation progress because FLL holders tend to delay the assessment because re-disturb is difficult to conduct ${ }^{10}$.

Reclamation must be completed at least a year before the FLL expiration date. Reclamation assessments are carried out after three years plantation and carried out by provincial team for FLL reclamation assessment. The assessment result was verified for a minimum of $5 \%$ from the total size of the assessed area by the provincial team as are set in the Minutes of Forest Reclamation Assessment. If FLL has expired, but FLL holder has not completed the reclamation, MoEF issues a maximum extension of 5 years to accomplish the reclamation only. At present, there is no low-cost reclamation monitoring and evaluation technology available. The current technology is still based on satellite imagery that requires high operational costs.

At present, there is no synchronization between the reclamation assessment and the certification of mining activities both at the central and regional levels in the form of the Corporate Performance Assessment Program called as PROPER. In addition, in relation to the assessment, some regulations weaken the capacity of the reclamation assessment team. The MoEF has a limited budget to support the assessment; thus, the cost is borne to FLL holders. This triggers a conflict of interest that affects the independence of the assessment results. In addition, verification by MoEF is double layer activity. Besides useful to increase the accuracy of the reclamation assessment, it also requires high operational cost, which has the same limitations as the assessment of the success of reclamation by provincial team $^{13}$.

From 90 FLL units, 22 units are expired and do not extend the license where 12 units do not have disturbed area and ten units have opened 1,303.42 ha of forest area with reclamation progress of 834.42 ha $(64.02 \%)$. From 55 mining license issued by local government holders, nine have not carried out reclamation of area $1,798.65$ ha where from 35 mining license issued by the central government, three units have not conducted reclamation in area of 155.07 ha. The mining permit holder must return reclamation land to the authority through the Director General of Mineral and Coal or governor after reclamation reached 100\% accomplished. Delays can be requested if the area is still needed for mining activity. Protection of reclamation area become the responsibility of FLL holder.

The reclamation progress of mining license issued by the central government is higher than mining license issued by local government holder. It also confirmed by Maharani et al. (2010) that big or trans-national mining companies generally have higher commitment to fulfill reclamation obligations compared with small mining companies that tend to have a low commitment to fulfill their reclamation obligations. FLL reclamation progress is also driven by access to increase FLL size of area quota and reduction of FLL levy. From 92010.73 hectares of FLL area borrowed by 55 unit of mining license issued by central government holders with the degraded area of 31,722.56 ha. Reclamation progress reached 14,048.97 ha $(44.29 \%)$ with the reclamation area returned to MoEF of 632.74 ha $(4.50 \%)$ over the degraded area. In the other hand, from 51,794.16 ha of FLL area borrowed by 35 unit of mining license issued by the local government with the degraded area of 5,957.42 ha. Reclamation progress reached $1,533.39$ ha $(25.74 \%)$ without any returned area to MoEF. One of causing triggers for higher reclamation progress of mining license issued by central government holders

\footnotetext{
${ }^{16}$ Information from members of the Provincial Team and MoEF Team for Mining Reclamation Assessment

${ }^{17}$ The results of a focus discussion group of "Mining Reclamation in Forest Area" conducted in Samarinda on April 17, 2018
} 
compared with mining license issued by local government holders is because mining license issued by central government operated since early of 1980s that in current period most mining license issued by central government enter rehabilitation phase after production phase while mining license issued by local government holders mostly started their operation from 2009 and accomplished in 2033.

A mining license holder who violates reclamation obligation is subjected to administrative sanctions in the form of written warnings, temporary termination of mining activities and mining license revocation. The sanction does not eliminate reclamation obligation. FLL holder that does not carry out reclamation is subjected to sanctions in the form of FLL reprimand or revocation. If the governor does not carry out reclamation evaluation or imposes sanctions on the violations, MoEMR can suspend or revoke the mining license, and the governor will be subjected to administrative sanctions in the form of temporary withdrawal of mining license issuance authority.

In fact, due to the implementation of mining reclamation obligation based FLL holder that its license period has expired and has not carried out reclamation is not sanctioned by MoEF. In addition, the governor who did not take action against the negligence of reclamation and reporting to MoEMR has not been sanctioned.

Reclamation progress is driven by access to increase FLL size quota and deduction of FLL levy. While in the other side, other FLL obligations namely watershed rehabilitation of FLL and Business to Business investment compensation agreements with Forest Utilization License holder become disincentives because they require high implementation costs that affect financial structure especially in mining license issued by local government holder ${ }^{14}$.

\section{Reclamation for non-forestry purpose utilization} Utilization planning of reclamation area determines the reclamation process. Utilization plan must consider the dependencies of local people of forest land. Reclamation must ensure that the final form of the reclamation area can provide benefits to local people under the management of FMU. For example, the implementation of the reclamation of one FLL holder in Berau District started by a study of land utilization based on the Provincial and District Spatial Planning, environmental impact analysis and the needs of related parties including local people surround mining area. That study resulted in a zoning pattern that consists of the utilization zone and buffer zone. Utilization zone is located close to the local community and is managed as integration between forestry and agricultural, plantation, cattle farming, fishery, water sports facilities, and water sources. While the buffer zone is the area used as forested areas to restore the buffer function and recreate habitat for local flora and fauna.

Mining must create benefits for many parties, including the local community, central and regional governments as well as the private sector in the mining business. In line with Kumar (2014), investment in the mining sector must be economically profitable, technologically appropriate and responsible for environmental and social conditions in the area around the mining site. In addition, the involvement of community roles is important in the management of FLL reclamation. Based on observations in 10 FLL holders in Berau District, West Kutai District, Kutai Kartanegara District, and Kutai Timur District, there are various patterns of utilization of reclamation areas that are being developed by FLL holders as part of reclamation activities.

The utilization of reclamation area can be developed as a business asset for FMU as site level forest manager subsequently after the FLL area is returned to MoEF. Patterns for the utilization of these areas include:

(1) Silvopasture. One commercial business that is very potential to be developed in the reclamation area in East Kalimantan Province is cattle farming. As the case of East Kalimantan Province experience, a deficit in meat supply and still relies on the supply of cattle from other regions such as Java and Bali. The development of cattle farms in the reclamation area potential because it is supported by the supply of animal feed from the cover crop or pruning from forest stands. In addition, livestock dung is very important for reclamation as fertilizer to improve soil properties to revegetation.

(2) Void utilization. The former mining area in void formation can be used as a source of clean water, water sports, fisheries or fishing recreation areas. This utilization must be based on hydrological and water quality studies to determine the safety of these functions.

(3) Utilization of multi-purpose tree species. Planting commercial tree species in the reclamation area can be combined with local tree species that produce resins, seeds, fruits, or other valuable products. The FLL holders commonly plant durian, jackfruit, candlenut, rambutan or breadfruit as local people requested to support their daily life with a maximum composition of $60 \%$ from total tree stands. In addition, non-timber species such as coffee, cocoa, dragon fruit, longan, paddy, or lemongrass can be combined with tree species and developed through agroforestry or agro-tourism.

(4) Utilization of landscapes. The reclamation landscape is potential to be developed into an arboretum or environmental education site, wildlife breeding area, hunting area, camping ground, recreational fishing, jogging track, outdoor sports arena, and outdoor playground.

Non-forestry development is potential to be developed in the forest area in particular in the reclamation area. There are FLL holders in Berau District and Kutai Kartanegara District have developed non-timber forest product such as lemongrass oil also rice production. In addition, the development of cattle farming in the reclamation area is also quite successful and potential to support food security in the region. However, these innovations are still carried out in the non-forest area since it is not in accordance with the criteria for successful FLL reclamation based on MoEF Decree Number 60/2009. However, until now there has been no policy that regulates incentives for FLL holders in developing non-forestry business in the reclamation area. The innovation in terms of regulation development to provide an economic incentive to FLL holder to shift reclamation as a cost center into a profit center is urgently required. Currently, the future to accommodate this innovation is by implementing social forestry and 
environmental partnership scheme as part of reclamation activity.

Reclamation product is a potential asset to be developed by the government. This is in accordance with the mandate of Article $66 \mathrm{MoEF}$ Decree Number 27/2018 which stipulates after FLL expiration, reclamation result belong to the state. Article 67 also stipulates that FLL reclamation result in a forest area that is not managed by any forest utilization license is handed over by Provincial Forestry Agency. It is beneficial not only to the economic structure of FLL but also to the economic development of local people.

Institutional performance of FLL reclamation Ostrom (1990) has noted several institutional performance indicators of resource management as follows (1) clarity of regional boundaries, (2) suitability between rule and local condition, (3) rules are prepared and implemented by resource users, (4) legitimate rule implementation, (5) sanctions mechanism can be enforced, 6) availability of conflict resolution mechanism, 7) strong government recognition by regulations, and 8) existence networking different institutions. Based on those indicators and implementation of mining reclamation as described above, the institutional performance of reclamation in East Kalimantan Province can be concluded (Table 2).

\section{Conclusion}

The institutional performance of mining reclamation in the forest area in East Kalimantan Province is strongly influenced by the institutional structure that is regulation governing FLL reclamation. It also influenced by the characteristic of the forest as mining operation area in particular related to the negative externalities caused by the mining operation and the existence of local community around FLL areas. Reclamation is high-cost activity with land management as the key phase and requires the biggest cost allocation Price of coal also significantly influenced reclamation progress. Regulation and forest characteristic shaped stakeholders' behavior. Low commitment to conducting FLL reclamation obligation by FLL holders and government apparatus existed. The commitment to fulfilling the reclamation business process obligation by FLL holders that holds mining license issued by the central government is higher than one that issued by the local government.

Table 2 Institutional performance of FLL reclamation in East Kalimantan

\begin{tabular}{|c|c|}
\hline Indicators & Findings \\
\hline Clarity of regional boundaries & $\begin{array}{l}\text { Boundaries of reclamation area is clearly defined in FLL contract between mining license holder } \\
\text { and MoEF. In fact, there are several FLL holders conduct their activity outside the FLL area but } \\
\text { conduct the reclamation only inside FLL area. So that, mining caused degradation to the forest but } \\
\text { the reclamation outside the forest areas is abandoned. The clarity of property right of FLL holder } \\
\text { is also lessen by strong position of local community who occupied of reclamation plantation. }\end{array}$ \\
\hline $\begin{array}{l}\text { Suitability between rule and local } \\
\text { condition }\end{array}$ & $\begin{array}{l}\text { Reclamation implementation based on successful reclamation criteria is not precisely suitable with } \\
\text { local condition. Some of the regulations is not clear or inflexible that limit the innovation by FLL } \\
\text { holders to shift reclamation from cost center into profit center that is beneficial as incentive for } \\
\text { FLL reclamation both for FLL holder and local community. }\end{array}$ \\
\hline $\begin{array}{l}\text { Rules are arranged and } \\
\text { implemented by resource users }\end{array}$ & $\begin{array}{l}\text { Regulations are set by the government and developed priodically to meet the needs offLL holder, } \\
\text { government and impacted party like local community. Those are implemented by related } \\
\text { stakeholders especially by FLL holder as regulation user as part of FLL contract obligations. The } \\
\text { absence of technical regulati on to support higher regulation limit the proper reclamation } \\
\text { implementation based on its business process. }\end{array}$ \\
\hline Legitimate rule implementation & $\begin{array}{l}\text { Regulation is legitimated by the stakeholders. The challenges including budget, human resource, } \\
\text { technology and regula tion shape stakeholders' behavior. The successful criteria of FLL } \\
\text { reclamation requires high reclamation cost that in particular FLL holders it impacts the profit and } \\
\text { lower the willingness of reclamation. }\end{array}$ \\
\hline Sanctions enforcement & $\begin{array}{l}\text { The obligation to conduct } r \text { eclamation business process is somehow still being ignored by the } \\
\text { stakeholders. Although violence of regulation happened, sanction mechanism is not enforced. }\end{array}$ \\
\hline $\begin{array}{l}\text { Availability of conflict resolution } \\
\text { mechanism }\end{array}$ & $\begin{array}{l}\text { There is no conflict resolution mechanism. Any conflict occurred in FLL reclamation activity } \\
\text { should be managed by FLL holder and conflicting party. }\end{array}$ \\
\hline $\begin{array}{l}\text { Strong government recognition by } \\
\text { regulations }\end{array}$ & $\begin{array}{l}\text { The most legitimate stakeholders is mining license issuer authority compard with MoEF that issue } \\
\text { FLL. Consequently, the regulation from mining sector is stronger than one governed by MoEF. } \\
\text { Furthermore, MoEMR or East Kalimantan Energy and Mineral Resource Agency are more } \\
\text { powerful compared with MoEF. }\end{array}$ \\
\hline $\begin{array}{l}\text { The existence networking different } \\
\text { institutions }\end{array}$ & $\begin{array}{l}\text { Reclamation elaborates many stakeholders with their role, capacity and interest. Mining } \\
\text { reclamation requires coordination among FLL holder, government institutions, local community, } \\
\text { academician and other related institutions from upstream to downstreamFLL reclamation business } \\
\text { process. }\end{array}$ \\
\hline
\end{tabular}

Note: FLL $=$ Forest lease-hold license

$\mathrm{MoEF}=$ Ministry of Environtment and Forestry

MoER $=$ Ministry of Energy and Mineral Resouce 
landscapes. Agriculture, Ecosystems and Environment, 163,85-93. https://doi.org/10.1016/j.agee.2012.04.022

\section{Recommendation}

Reclamation of FLL in this province is less than half of total degraded area, but the progress is possible to enhance if FLL holders commit to conduct FLL reclamation business process sequence. It will require more high skill human resource, coordination among stakeholders, and low-cost technology in implementation and its monitoring and evaluation. Improvement of regulation that applies in the field, lessen conflict of interest, engage integrated stakeholders and phases from upstream to downstream reclamation business process, ensure law enforcement and provide the economic incentive that shifts reclamation from cost center into benefit center is also urgently required to enhance performance of mining reclamation in forest areas in East Kalimantan.

\section{References}

Ai-bin, Li., Mina, Z., \& Ming-yin, L. (2009). Economic analysis and realization mechanism design for full cost of coal mining. Procedia Earth and Planetary Science, 1, 1686-1694. https://doi.org/10.1016/j.proeps.2009 .09 .259

Anawar, H. Md. (2015). Sustainable rehabilitation of mining waste and acid mine drainage using geochemistry, mine type, mineralogy, texture, ore extraction and climate knowledge. Journal of Environmental Management, 158, 111-121.https://doi.org/10.1016/j.jenvman.2015.04.045

Article 33. (2014). Research Report 2014: Analysis of lost potency of forest leasehold license for mining.

Azrin, D. (2016). Environmental aspects on coal mining in Indonesia. Forest reclamation in post mining land forum Japan International Forestry Promotion, 4 February 2016. Jakarta.

Chang-sheng, J., Zhao-xue, C., \& Qing-hua, C. (2009). Surface coal mining practice in China. Proceedings of the 6th International Conference on Mining Science \& Technology. Procedia Earth and Planetary Science, 1(1), 76-80. https://doi.org/10.1016/j.proeps.2009.09.014

Creswell, J. W. (2016). Pendekatan metode kualitatif, kuantitatif, dan campuran. Translated from: Research design: Qualitative, quantitative, and mix method approach $\left(4^{\text {th }}\right.$ ed.). Yogyakarta: Pustaka Pelajar

Dariah, A., Abdulrachman, A., \& Subardja, D. (2009). Reklamasi lahan eks-penambangan untuk perluasan areal pertanian. Jurnal Sumberdaya Lahan, 4(1).

[DG Mineral and Coal] Directorate General of Mineral and Coal, Ministry of Energy and Mineral Resource. (2015). Annual report 2015.

Doley, D., Audet, P., \& Mulligan, D. R. (2012). Examining the Australian context for post-mined land rehabilitation: Reconciling a paradigm for the development of natural and novel ecosystems among post-disturbance
Fahruddin, \& Abdullah, A. (2013). Dinamika populasi bakteri pada sedimen yang diperlakukan dengan air asam tambang. Jurnal Alam dan Lingkungan, 4(7), 39-44.

Fischer, A., Petersen, L., Feldkötter, C., \& Huppert W. 2007. Sustainable governance of natural resources and institutional change-an analytical framework. Public Administration and Development, 27, 123-137. https://doi.org/10.1002/pad.442

Gossum, P. V., Arts, B., \& Verheyen, K. (2012). "Smart regulation": Can policy instrument design solve forest policy aims of expansion and sustainability in Flanders and the Netherlands? Forest Policy and Economics, 16, 23-34. https://doi.org/10.1016/j.forpol.2009.08.010

Gradinaru, G. (2014). A business perspective of a natural capital restoration. Procedia Economics and Finance, 10, 97-103. https://doi.org/10.1016/S2212-5671 (14)00282-2

Gunarto, T., Darusman, D., Sutjahjo, S. H., \& Ramdan, H. (2009). Analisis pengembangan kelembagaan asuransi lingkungan. Jurnal Bisnis \& Manajemen, 6(1), 13-29.

Hall, D. (1987). Reclamation planning for coal strip-mined lands in Montana. Landscape and Urban Planning, 14, 45-55. https://doi.org/10.1016/0169-2046(87)90005-3

Hirons, M., Hilson, G., Asase, A., \& Hodson, M. E. (2013). Mining in a changing climate: what scope for forestrybased legacies? Journal of Cleaner Production, 8, 430-438. https://doi.org/10.1016/j.jclepro.2013.11.025

Kumar, N. P. (2014). Review on sustainable mining practice. International Research Journal of Earth Sciences, 2(10), 26-29.

Lin-lin, C., \& Zhen-qi, H. (2009). Economic-theory-based analysis of the collection standard of mine land reclamation bond and its calculation approach. Procedia Earth and Planetary Science, 1, 1275-1279. https://doi.org/10.1016/j.proeps.2009.09.197

Mansur, I. (2017). Mengembalikan produktivitas lahan bekas tambang di Indonesia. Forest Digest Edisi ke-3.

[MoEMR] Ministry of Energy and Mineral Resource. (2018). Handbook of Energy \& Economic Statistic of Indonesia. Jakarta: Ministry of Energy and Mineral Resouce.

Muis, H., Jaya, I N. S., Saleh, B., \& Murtilaksono, K. 2016. Information required for estimating the indicator of forest reclamation success in ex-coal mining area. Indonesian Journal of Electrical Engineering and Computer Science, 3(1), 182-193.

Nasir, S., Purba, M., \& Sihombing, O. (2014). Pengolahan air asam tambang dengan menggunakan membran 
keramik berbahan tanah liat, tepung jagung dan serbuk besi. Jurnal Teknik Kimia , 3(20), 22-30.

Nopyandri. (2014). Penerapan prinsip Good Environmental Governance dalam rangka perlindungan dan pengelolaan lingkungan hidup. Jurnal Ilmu Hukum, 80-94.

Nugroho, B. (2016). Kelembagaan, karakteristik sumberdaya dan perilaku aktor: Analisis kritis kinerja kebijakan pengelolaan hutan Indonesia. [Orasi ilmiah guru besar IPB.]. Bogor: IPB University.

Ostrom E. (1990). Governing the commons: The evolution of institution for collective actions. New York: Cambridge University Press.

Peck, P., \& Sinding, K. (2009). Financial assurance and mine closure: Stakeholder expectations and effects on operating decisions. Resource Policy, 34, 227-233. https://doi.org/10.1016/j/resourpol.2009.03.001

Pohan, C. A. (2014). Cadangan reklamasi pertambangan sebagai loopholes pajak dalam penerapan prinsip taxability-deductibility. Transparansi: Jurnal Ilmiah Ilmu Administrasi, 6(2), 181-198.

Polit, D. F., \& Beck, C. T. (2012). Resource manual for nursing research: Generating and assessing evidence for nursing practice. $\left(9^{\text {th }}\right.$ ed.) Philadelphia: Wolters Kluwer Health, Lippincott Williams \& Wilkins.

Rosli, A., \& Rossi, F. (2014). Explaining the gap between policy aspirations and implementation: The case of university knowledge transfer policy in the United Kingdom. CIMR Research Working Paper Series No. 20.
Saria, L. (2016). Environmental protection of mineral and coal in Indonesia. Paper presented at the Forest Reclamation in Post Mining Land Forum-Japan International Forestry Promotion, 4 February 2016. Jakarta, Indonesia.

Sartika, E. (2014). Analisis isi kualitatif pesan moral dalam film berjudul "Kita versus Korupsi". Jurnal Ilmu Komunikasi, 2(2), 63-77.

Schmid, A. A. 1987. Property, power and public choice. An inquiry into law and economics ( $2^{\text {nd }}$ ed.). New York: Praeger.

Statistics Indonesia. (2018). Statistics Indonesia 2018. Retrieved from https://www.bps.go.id/publication/2018/ 07/03/5a963c1 ea9b0fed6497d0845/statistik-indonesia2018

Suryanto, \& Fernandes, A. (2010). Sosial ekonomi reklamasi batubara. status riset reklamasi bekas tambang batubara. Samarinda: Balai Besar Penelitian Dipterokarpa.

Syaprudin, Bakrie, I., \& Kamarubayana, L. (2014). Pinjam pakai kawasan hutan dan realisasi pemanfaatannya oleh PT Mahakam Sumber Jaya di Kabupaten Kutai Kartanegara Provinsi Kalimantan Timur. Jurnal Agrifor, 13(1), 93-104.

Zubayr, M. (2014). Implementasi kebijakan penggunaan kawasan hutan untuk pertambangan: Perspekstif hubungan Principal-Agent Relations [dissertation]. Bogor: IPB University. 